\title{
Manfaat dan Hambatan Problem-Based Learning (PBL) Menurut Perspektif Mahasiswa Baru di Fakultas Kedokteran Universitas Riau
}

\author{
Enikarmila Asni ${ }^{1}$, M. Yulis Hamidy ${ }^{2}$
}

\begin{abstract}
Problem-based learning (PBL) has been adopted in medical faculty and sometimes produced students' anxieties. This qualitative research will gathered the information of students' condition based on their perspectives in strengths and difficulties of adapting PBL in Medical Faculty of Riau University. Data were collected by questionnaires and reflective assay. These data will be analyzed and grouped based on the themes and meaning by researcher. Result showed that the strengths of PBL based on students perspectives were increasing in skill of teamwork, speaking, active learning, communicating, and critical thinking. In the other hand, students' perspectives of PB L difficulties after first tutorial were internal types such as lack of knowledge in PBL and in topic of discussion, but after first session, the difficulties were external types such as; heavy workload, limited sources of literatures.
\end{abstract}

Keywords: problem-based learning, students, adaptation, strength, difficulties.

Problem-Based Learning (PBL) pertama kali dikembangkan di Fakultas Kedokteran oleh Universitas McMaster, Ontario pada tahun 1965. ${ }^{1}$ Sejak saat itu, metode ini digunakan secara luas oleh fakultas kedokteran lainnya. Fakultas Kedokteran Universitas Riau pertama kali mengenalkan PBL sebagai salah satu mata kuliah yang bersifat pilihan pada tahun 2005 dan diterapkan secara penuh sejak tahun 2007.

Berbagai bukti menunjukkan kelebihan metode PBL dibandingkan metode konvensional. Namun di lain pihak, metode PBL juga mengurangi beberapa kelebihan yang diperoleh dari metode kuliah secara konvensional. Sifat alami PBL yang menimbulkan ketidakpastian dalam proses belajar kadangkala mendatangkan rasa cemas dan frustasi baik bagi mahasiswa sendiri dan juga fasilitator. ${ }^{2}$ Sebenarnya ini bertujuan memotivasi keingintahuan mahasiswa

1 Penulis untuk korespondensi; Alamat: Unit Pendidikan Kedokteran (Medical Education Unit) Fakultas Kedokteran Universitas Riau Jl. Diponegoro No.1 Pekanbaru, Riau, 28111 Telp.0761 839264 Fax.0761-839265 email: eni93@yahoo.com

2 Unit Pendidikan Kedokteran (Medical Education Unit) Fakultas Kedokteran Universitas Riau sendiri untuk lebih aktif mencari dan tidak lagi tergantung kepada guru/dosen. ${ }^{3-7}$ Oleh karena itu metode PBL memerlukan sumber dan fasilitas pendukung seperti, bahan bacaan, internet, dan ruangan, yang relatif lebih banyak dibandingkan perkuliahan konvensional. ${ }^{8}$

Penerapan PBL akan menimbulkan kecemasan bagi mahasiswa terutama yang tidak mengalami proses belajar mengajar secara PBL sebelumnya. Fakultas Kedokteran Universitas Riau (FKUR) telah melakukan beberapa kegiatan yang bertujuan untuk mendukung pelaksanaan PBL seperti perekrutan tutor/fasilitator, pelatihan tutor/fasilitator, perbaikan sistem penilaian dan evaluasi serta persiapan perpustakaan. Namun belum ada penelitian sisi manfaat dan hambatan yang dirasakan mahasiswa terutama mahasiswa tahun pertama dalam beradaptasi dengan sistem PBL.

Oleh karena itu, penelitian ini bertujuan untuk menganalisis perspektif mahasiswa baru mengenai manfaat dan hambatan yang dirasakan terhadap PBL. Data ini diharapkan bermanfaat dalam mengevaluasi dan meningkatkan pelaksanaan PBL di masa yang akan datang. 


\section{METODE}

Penelitian ini bersifat kualitatif dengan membaca dan menganalisis setiap tema yang muncul pada jawaban dari pertanyaan terbuka yang diajukan oleh peneliti. Setiap kata dikelompokkan sesuai dengan makna/arti yang terkandung didalamnya. Jika kelima jawaban memiliki arti yang sama/ pengulangan maka dianggap satu, sedangkan satu kalimat yang mengandung arti berbeda akan dipisahkan sesuai artinya masing-masing. Populasi penelitian adalah seluruh mahasiswa FKUR angkatan 2008-2009 terdiri dari 117 orang. Setiap kali pemberian kuisioner disiapkan untuk keseluruhan (117) mahasiswa. Mahasiswa yang bersedia menjadi sampel penelitian yaitu 102 orang setelah satu kali tutorial dan 116 orang setelah mengalami satu sesi PBL. Sampel penelitian yaitu mahasiswa yang bersedia berpartisipasi dalam penelitian ini yang dinyatakan dengan penyetujuan informed consent. Kuesioner berupa pertanyaan terbuka tentang 5 manfaat PBL yang dirasakan dan
5 hambatan yang dirasakan selama PBL diajukan setelah tutorial pertama. Pertanyaan dicantumkan di kuesioner dan dijelaskan terlebih dahulu kepada mahasiswa secara kolektif. Reflektif esai dilakukan setelah selesai PBL pertama (dua kali diskusi tutorial dan satu kali pleno). Isi dari reflektif esai akan dianalisis dengan mengartikan dan mengelompokkan makna setiap pernyataan yang timbul.

\section{HASIL}

\section{Manfaat PBL}

Manfaat PBL telah dirasakan setelah diskusi kelompok pertama kalinya (Gambar 1). Manfaat PBL yang dirasakan setelah 1 kali tutorial yang dominan dinyatakan adalah kebersamaan kelompok, keberanian mengemukakan pendapat, menimbulkan keaktifan, menambah keterampilan komunikasi dan meningkatkan pola pikir kritis.

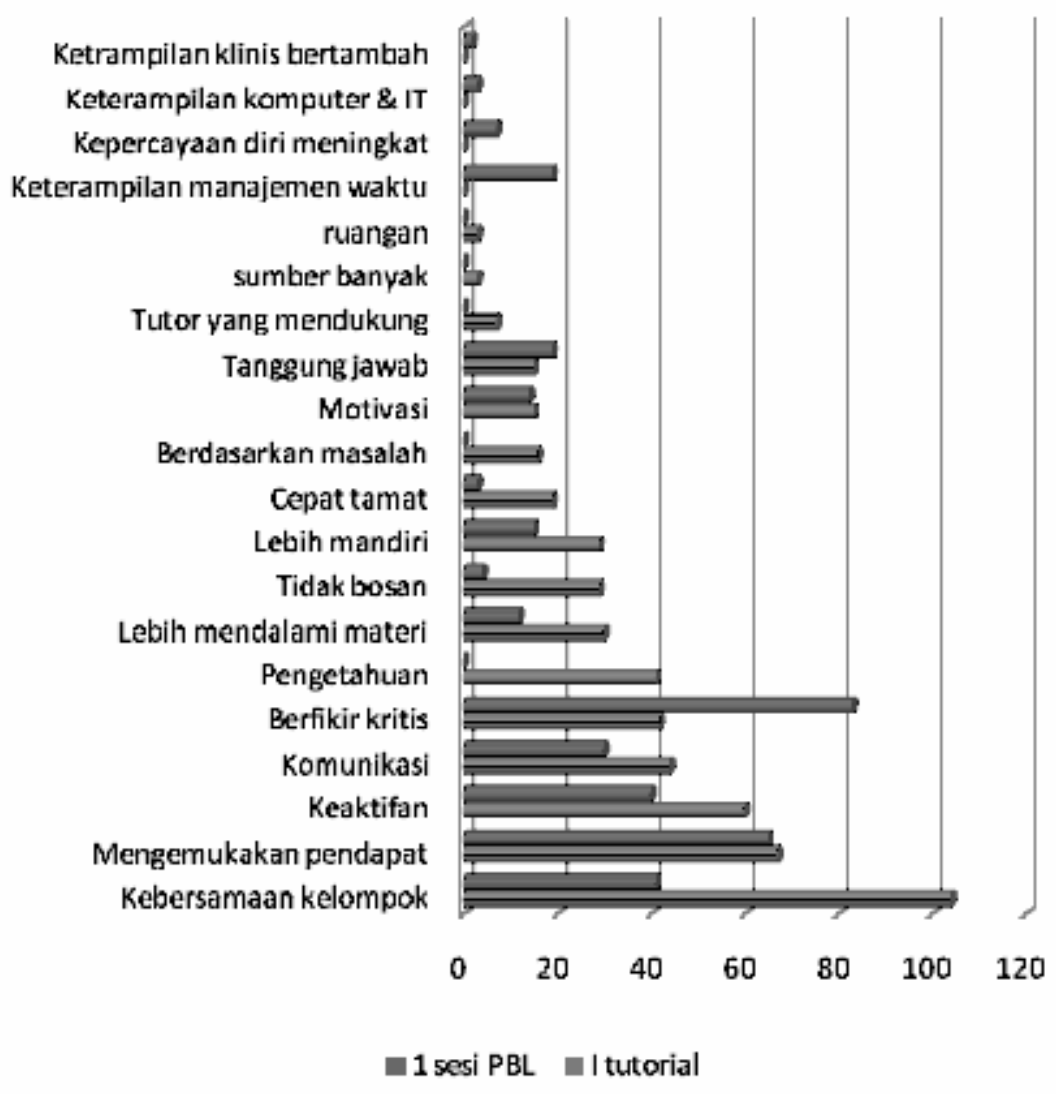

Gambar 1. Manfaat PBL yang dirasakan mahasiswa setelah 1 kali tutorial dan 1 kali sesi PBL 
Setelah 1 sesi PBL, manfaat yang dirasakan sama namun dalam urutan yang berbeda dimana meningkatkan pola fikir kritis menjadi manfaat utama yang dirasakan. Selanjutnya keberanian mengemukakan pendapat, kebersamaan kelompok, menimbulkan keaktifan, dan menambah keterampilan komunikasi. Selain manfaat dalam meningkatkan pola fikir kritis dan menimbulkan keaktifan, mahasiswa juga merasa memiliki keterampilan klinis serta belajar lebih terarah karena berdasarkan masalah.

Hambatan PBL

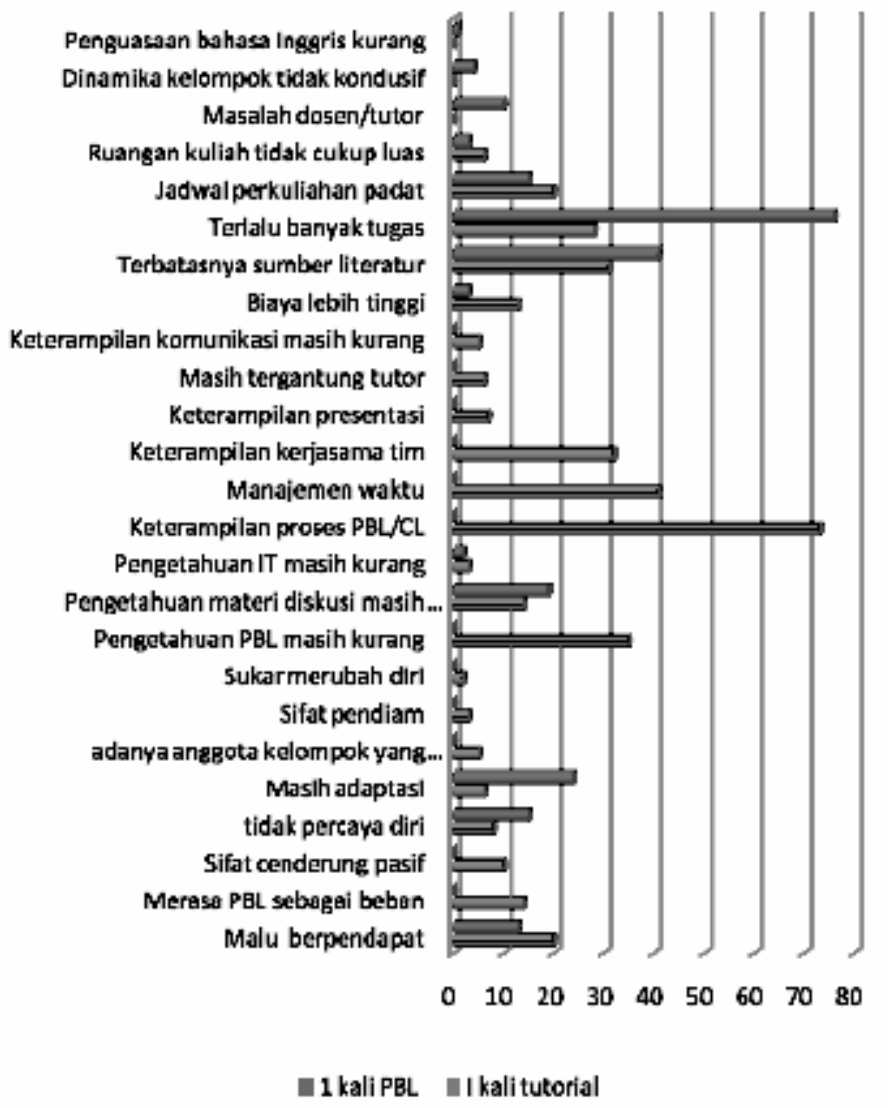

Gambar 2. Hambatan PBL yang dirasakan mahasiswa setelah 1 kali tutorial dan 1 kali sesi PBL

Hambatan utama yang dirasakan mahasiswa baru dalam melaksanakan PBL dapat dilihat pada Gambar 2. Setelah tutorial untuk pertama kalinya, hambatan terutama berasal dari hambatan internal yaitu kurangnya keterampilan dan pengetahuan pelaksanaan PBL/CL, manajemen waktu, kerjasama dalam tim/kelompok serta keberanian untuk mengeluarkan pendapat. Beberapa hambatan eksternal yang juga dirasakan adalah keterbatasan literatur, terlalu banyak tugas dan padatnya jadwal perkuliahan. Setelah satu kali sesi PBL, hambatan yang dirasakan terutama berasal dari hambatan eksternal yaitu keterbatasan literatur, terlalu banyak tugas dan padatnya jadwal perkuliahan. Beberapa mahasiswa menyatakan sistem ini butuh biaya yang lebih tinggi karena kebutuhan terhadap komputer dan internet meningkat. Memiliki laptop sepertinya menjadi kebutuhan perkuliahan di fakultas dengan sistem ini.

\section{PEMBAHASAN}

\section{Manfaat PBL}

Perspektif mahasiswa FKUR ketika pertama kali diskusi kelompok PBL telah menggambarkan 
kelebihan PBL dibandingkan metode konvensional seperti kebersamaan kelompok, keberanian mengemukakan pendapat, menimbulkan keaktifan, menambah keterampilan komunikasi dan meningkatkan pola pikir kritis. Manfaat yang utama dirasakan pada saat ini adalah manfaat bekerja dalam kelompok. Hal ini juga ditemukan Moore $e t$ al (1994) ${ }^{9}$ di Harvard Medical School yang menyatakan bahwa mahasiswa PBL lebih reflektif, aktif, mandiri, inovatif dan lebih mudah bekerja dalam kelompok dibandingkan mahasiswa yang belajar secara konvensional. Mahasiswa PBL mendefinisikan masa belajarnya "menarik, sulit, dan berguna" sedangkan sebaliknya mahasiswa konvensional mendefinisikan "tidak relevan, pasif dan membosankan".

Manfaat setelah 1 sesi PBL yang terdiri dari tutorial pertama (langkah 1-4 metode seven jump), tutorial kedua (langkah 5-7 metode seven jump) dan pleno yang mengulas kembali hasil diskusi dengan pakar, manfaat yang dirasakan yaitu meningkatkan pola fikir kritis. Terjadi peningkatan ke diri/"self" mahasiswa sendiri yang dapat diakibatkan dengan usaha mencari learning issue dan membahasnya kembali dalam kelompok. Manfaat dalam kelompok masih dirasakan, disamping itu mahasiswa juga merasa memiliki keterampilan klinis serta belajar lebih terarah karena berdasarkan masalah. Manfaat yang sama juga ditemukan Dehkordi dan Heydarnejad $(2008)^{10}$ dimana mahasiswa keperawatan yang mendapatkan PBL lebih memiliki motivasi yang tinggi dalam belajar dibandingkan metode konvensional. Tiwari et al.(2006) ${ }^{11}$ juga menemukan bahwa terdapat peningkatan daya berfikir kritis mahasiswa PBL dibandingkan metode konvensional.

Manfaat PBL terhadap perkembangan diri menjadi pribadi yang self directed learning baru mulai dirasakan setelah menyelesaikan tugas yang diberikan setelah tutorial pertama secara mandiri. Hal ini menggambarkan bahwa PBL selain menciptakan suasana yang nyaman juga mendukung untuk belajar secara mandiri dengan pendekatan belajar yang lebih mendalam. . $^{3-5,12-14}$

Mahasiswa diharapkan belajar untuk mengerti, bukan menghapal sehingga memicu keaktifan untuk mencari informasi secara mandiri serta memiliki keterampilan dalam pencarian informasi seperti penggunaan komputer dan internet. ${ }^{15}$

Nilai positif PBL didapatkan Nandi et al $(2000)^{16}$ pada penelitiannya di Hongkong bahwa komunikasi dosen-mahasiswa lebih interaktif dan mahasiswa menjadi lebih komunikatif, inisiatif dan lebih siap untuk kondisi perkuliahan klinik karena memiliki keterampilan bertanya dan problemsolving.

Mahasiswa menyatakan bahwa metode PBL lebih cepat menyelesaikan pendidikan kedokteran dibandingkan konvensional. Hal ini karena di FKUR, metode PBL memang dipetakan untuk diselesaikan dalam kurun waktu 5 tahun yang setahun lebih awal jika dibandingkan metode konvensional yang 6 tahun.

\section{Hambatan PBL}

Berdasarkan sumber utama, hambatan dalam menjalani PBL dapat dibagi atas 2 kelompok yaitu: hambatan internal (yang bersumber dari dalam diri mahasiswa tersebut), hambatan eksternal (yang berasal dari luar mahasiswa). Hambatan internal bersumber dari sifat, pengetahuan dan keterampilan mahasiswa sedangkan eksternal dapat berhubungan dengan sistem di fakultas kedokteran dan yang berhubungan dengan biaya.

Mahasiswa merasakan bahwa semakin kompleks perkuliahan semakin kompleks pula hambatan yang dirasakan. Hambatan internal yang dirasakan setelah tutorial untuk pertama kalinya berkembang menjadi hambatan eksternal yaitu keterbatasan literatur, terlalu banyak tugas dan padatnya jadwal perkuliahan.

Mahasiwa FKUR berasal dari pendidikan menengah atas (undergraduated medical education) yang masih berusia relatif muda dan cenderung kurang pengalaman dalam PBL. Hal ini yang dominan mendatangkan kecemasan dalam hal pengetahuan dan keterampilan untuk menjalani PBL dan mengambil kendali proses belajar mengajar. Hal ini membutuhkan proses PBL yang nyaman untuk belajar tanpa mengenyampingkan pemenuhan pengetahuan dasar dan keterampilan klinis. ${ }^{17-18}$

Kondisi yang nyaman ini membutuhkan dukungan terutama tutor ataupun fasilitator. Budaya dapat memegang peranan hubungan mahasiswa 
dengan tutor seperti adanya penelitian yang menyatakan bahwa beberapa sikap di Asia yang tidak mendukung penerapan PBL. Sikap ini antara lain yaitu ketakutan untuk konfrontasi, mengkritik, ketergantungan yang berlebihan dan penghormatan yang sangat tinggi pada pihak yang berwenang (dalam hal ini guru). Mahasiswa menjadi takut berbicara terbuka, kehilangan keinginan untuk belajar, malas bertanya dan kurang berpartisipasi dalam diskusi kelas. Kebiasaan untuk menempatkan kepentingan kelompok dibandingkan individu juga akan mengakibatkan hal yang berlawanan dengan tujuan PBL dalam meningkatkan kemampuan untuk berpikir secara kritis. ${ }^{19}$

Peranan pendidik sebagai "sumber" pengetahuan akan berkurang dan digantikan menjadi "fasilitator" untuk memperoleh pengetahuan. Keadaan ini akan mengakibatkan kecemasan bukan hanya terhadap mahasiswa juga terhadap pendidik yang telah terbiasa dengan peranan mereka untuk memberikan kuliah bukan memfasilitasi proses belajar mahasiswa. Selain itu peranan pendidik sebagai "role model" tidak akan sekuat pada metode kuliah konvensional. ${ }^{3,7}$

Kesulitan yang dirasakan dalam pengetahuan dan keterampilan PBL dapat diatasi dengan diberikannya mahasiswa beradaptasi terlebih dahulu sampai mengerti dan memahami proses PBL sebelum melangkah ke topik lain di fakultas kedokteran yang lebih kompleks. Pengetahuan dan keterampilan akan berkembang seperti spiral. Kesulitan dalam ujian ilmu pengetahuan dasar (biomedik) dibandingkan kurikulum konvensional dapat diatasi sesuai dengan Mennin et al (1993) ${ }^{20}$ yang menyatakan metode teacher-centred dan terstruktur dapat lebih baik dalam mengajarkan ilmu biomedik dasar. Sehingga pada masa adaptasi awal mungkin perkuliahan tetap diberikan dalam jam yang relatif lebih banyak. Fyrenius, Bergdahl, dan Silén (2005) ${ }^{21}$ menyatakan bahwa dengan metode penyampaian yang menghindari surface learning, teacher centered dan mahasiswa yang pasif, perkuliahan dapat menjadi salah satu alat pembelajaran yang baik untuk PBL. Selanjutnya perkuliahan dapat dikurangi karena metode ini kurang efektif dalam menyampaikan instruksi. ${ }^{22}$

Hambatan dalam keterbatasan literatur, jumlah tugas dan waktu perkuliahan memerlukan penelitian yang lebih lanjut. Hal ini jika menjadi beban akan mengakibatkan mahasiswa cenderung menolak PBL. Fakultas sebaiknya mempersiapkan sarana dan prasarana pendukung yang cukup seperti perpustakaan dan juga staf yang dapat memberikan bimbingan baik mengenai pencarían literatur, pelatihan cara membaca dan menilai bahan bacaan, juga bimbingan konseling mengenai manajemen waktu yang baik. Diharapkan semua ini tersedia bukan hanya diberikan dalam perkuliahan namun tersedia dalam suatu unit dimana mahasiswa bisa melakukan konsultasi setiap saat. Selain itu, evaluasi perlu dilakukan secara berkelanjutan untuk mencegah adanya perkuliahan yang terlalu padat dan tugas yang terlalu banyak sehingga mahasiswa tidak memiliki waktu lagi untuk melakukan "refleksi" sebagai inti sesungguhnya dari PBL. Hal ini seperti yang dinyatakan Dolman et al. (2002) ${ }^{23}$ dimana fakultas dan pemegang kebijaksanaan diharapkan memiliki komitmen dalam memperbaiki dan mengevaluasi desain kurikulum, kasus, dan juga memicu perkembangan keterampilan tutor.

Hal ini yang menjadi perhatian karena keberhasilan PBL juga dipengaruhi dengan kesiapan fakultas. Kesiapan fakultas bukan hanya menyiapkan dan melatih tutor tetapi mencakup kesiapan semua sivitas akademika kampus mulai dari jenjang paling atas setingkat universitas sampai prasarana lainnya di kampus. Hitchcock dan Mylona $(2000)^{24}$ menyatakan bahwa tidak tersedia data yang memadai untuk menunjukkan apa yang dibutuhkan suatu fakultas untuk dapat berkembang dari sistem tradisional ke sistem PBL. Karena itu fakultas juga membutuhkan pelatihan dan bimbingan secara berkelanjutan.

Mahasiswa mulai dapat membandingkan tutor setelah 1 kali PBL dibandingkan satu kali tutorial. Sikap tutor yang tidak mendukung seperti keterlambatan, terlalu pasif, ataupun terlalu aktif dapat mengganggu tercapainya tujuan PBL. Proses tutorial masih berjalan dalam variasi yang cukup besar karena untuk mencukupkan kebutuhan tutor terkadang fakultas menggunakan tutor yang tidak berlatar belakang medis ataupun yang tidak memiliki keterampilan PBL. Hal ini selayaknya menjadi prioritas fakultas untuk memenuhi ketersediaan tutor yang cukup baik dari segi kuantitas maupun dari segi kualitas. ${ }^{22}$ 
Beberapa kelemahan dalam penelitian ini adalah perbedaan interpretasi peneliti dengan responden karena data didapatkan hanya dari tulisan dan tidak dilanjutkan dengan wawancara yang lebih mendalam. Kelemahan lainnya yaitu penulisan reflektif esai relatif masih baru bagi mahasiswa. Masih ada kecenderungan untuk tidak mengungkapkan sejujurnya tanpa paksaan, bahkan ada satu mahasiswa yang mengumpulkan esai yang disalin dari temannya. Hal ini masih memerlukan latihan di masa yang akan datang serta mampu menghadirkan kenyamanan mahasiswa untuk menuliskan keadaannya dengan jujur.

\section{KESIMPULAN}

Dari penelitian ini didapatkan bahwa mahasiswa FK Unri angkatan 2008 telah mendapatkan manfaat dari pelaksaanaan PBL pada saat pertama kali mengalami satu kali tutorial dan sesi PBL. Bersamaan dengan itu, hambatan dalam pelaksanaan PBL juga dirasakan. Hambatan ini baik internal dan eksternal memerlukan intervensi fakultas sehingga tidak berlanjut dan malah menghambat pelaksanaan PBL di kemudian hari. Hambatan internal dapat diatasi dengan penyediaan bantuan bimbingan yang berkelanjutan, bukan hanya di awal PBL. Hambatan eksternal membutuhkan evaluasi dan intervensi yang lebih lanjut, baik dalam pemenuhan sarana dan prasarana juga sumber daya manusia yang dibutuhkan.

\section{UCAPAN TERIMA KASIH}

Penelitian ini didanai Dana DIPA PNBP Tahun 2009 Universitas Riau. Dalam kesempatan ini peneliti mengucapkan terima kasih kepada Dekan Fakultas Kedokteran Universitas Riau atas dukungannya dalam penelitian di FK UR ini. Terima kasih juga kepada seluruh mahasiswa FK UR khususnya angkatan 2008 yang telah berpartisipasi aktif sebagai responden dalam penelitian ini serta seluruh pihak yang telah membantu peneliti dalam melaksanakan penelitian ini. Semoga Allah S.W.T berkenan membalas segala kebaikan semua pihak yang telah membantu.

\section{DAFTAR PUSTAKA}

1. Neville AJ, Norman GR. PBL in the undergraduate MD program at McMaster University: Three iterations in three decades. Academic Medicine. 2007;82(4):370-74.

2. Weiss RA. Designing problems to promote higher-order thinking. New Direction For Teaching And Learning. 2003; 95: 25-31.

3. Davis MH, Harden RM. AMEE Medical Education Guide No. 15: Problem-based learning: a practical guide. Medical Teacher. 1999;21(2):130-40.

4. Antepohl W, Domeij E, Forsberg P, dan Ludvigsson J. A follow-up of medical graduates of a problem-based learning curriculum. Medical Education. 2003;37:155-62.

5. Wood DF. ABC of learning and teaching in medicine: Problem based learning. BMJ 2003;326: 328-30.

6. Azer SA. Challenges facing PBL tutors: 12 tips for successful group facilitation. Medical Teacher. 2005; 27(8): 676-81.

7. Jung B, Tryssenaar J, dan Wilkins S. Becoming a tutor: exploring the learning experiences and needs of novice tutors in a PBL programme. Medical Teacher. 2005; 27(7): 606-12.

8. Tärnvik A. Revival of the case method: a way to retain student-centred learning in a post-PBL era. Medical Teacher. 2007;29(1):e32 - e36.

9. Moore GT, Block SD, Style CB, Mitchell R. The influence of the New Pathway curriculum on Harvard medical students. Acad Med. 1994; 69:983-9.

10.Dehkordi AH, Heydarnejad MS. The impact of problem-based learning and lecturing on the behavior and attitudes of Iranian nursing students. A randomised controlled trial. Dan Med Bull. 2008; 55(4): 224-6.

11.Tiwari, A., Lai, P., So, M., andYuen, K A. Comparison of the effects of problem-based learning and lecturing on the development of students' critical thinking. Med Educ. 2006; 40(6): 547-54. 
12.Antepohl W, Herzig S. Problem-based learning versus lecture-based learning in a course of basic pharmacology: a controlled, randomized study. Medical Education. 1999; 33: 106-113.

13.Dochy F, Segers M, Bossche PVD, dan Gijbels D. Effects of problem-based learning: a metaanalysis. Learning and Instruction. 2003; 13: 533-68.

14.Gijbels D, Dochy F, Bossche PVD, Segers M. Effects of problem-based learning: A metaanalysis from the angle of assessment. Review of Educational Research. 2005; 75(1): 27-61.

15.Rankin JA. Problem-based medical education: effect on library use. Bull Med Libr Assoc. 1992;80:36-43.

16.Nandi PL, Chan JNF, Chan CPK, Chan P, dan Chan LPK. Undergraduate medical education: comparison of problem-based learning and conventional teaching. HKMJ. 2000; 6: 301-6.

17. Weatherall DJ. The inhumanity of medicine. BMJ. 1994;308:1671-2.

18.Dowie R, Charlton B. The making of a doctor. Oxford:Oxford University, 1994.
19. Khoo HE. Implementation of problem-based learning in Asian medical schools and students' perceptions of their experience. Medical Education. 2003; 37: 401- 9.

20.Friedman CP, de Bliek R, Greer DS, et al. Charting the winds of change: evaluating innovative medical curricula. Acad Med. 1990; 65: 8-14.

21.Fyrenius A, Bergdahl B, Silén C. Lectures in problem-based learning-why, when and how? An example of interactive lecturing that stimulates meaningful learning. Med Teach. 2005; 27(1): 61-5.

22. Albanese MA, Mitchell S. Problem-based learning: a review of literature on its outcomes and implementation of issues. Acad Med. 1993; 68: 52-81.

23.Dolmans DH, Gijselaers WH, Moust JH, de Grave WS, Wolfhagen IH, van der Vleuten CP. Trends in research on the tutor in problem-based learning: conclusions and implications for educational practice and research. Med Teach. 2002 Mar; 24(2): 173-80.

24. Hitchcock MA, Mylona ZH.Teaching faculty to conduct problem-based learning. Teach Learn Med. 2000; 12(1): 52-7. 